\section{Politics of evidence}

\author{
Philip Wiffen
}

Evidence as expressed in the framework of evidence-based medicine has always caused controversy. In the early days, it was resisted by senior and experienced clinicians who did not like to be told what to do-even if they were wrong! On the face of it, the well-known definition by Sackett seems sensible and benign. Published 25 years ago, it stated 'Evidencebased medicine is the conscientious, explicit and judicious use of current best evidence in making decisions about the care of individual patients'. ${ }^{1}$ In the current pandemic, we might want to amend the last part to 'about the care of populations'.

So what in the world is going on with coronavirus vaccines? Why is such an important and life-saving intervention being highjacked by politicians who probably have little understanding of evidence either from randomised trials or from so-called 'real-world evidence'? We have at least one country stating than one vaccine is not effective in over 65 s then reversing that decision and stating it should not be given to under 65s! In AD 64, Emperor

Pain Research Unit, Churchill Hospital, Oxford, UK

Correspondence to Professor Philip Wiffen, Pain Research Unit, Churchill Hospital, Oxford OX3 7LE, UK; pwiffen@oxfordsrs.org.uk
Nero was accused of fiddling while Rome burned. It was a reference to not only was he playing music but also that he was an ineffective leader. In the current situation, we have a situation where politicians are meddling while people die.

Then of course there has been the controversy over blood clots and the AstraZeneca vaccine. A detailed search found little that was trustworthy, though there is plenty of rhetoric and comment. Even the major medical journals seem to have little to say. The most definitive comment is from the European Medicines Agency, stating 'EMA currently remains of the view that the benefits of the AstraZeneca vaccine in preventing COVID-19, with its associated risk of hospitalisation and death, outweigh the risks of side effects'. ${ }^{2}$

It is no wonder that members of the public across Europe are confused, and this has led to the rise of so called antivaxxers, that is, people who do not want or trust the vaccine. In the UK, this has been evident in the black, Asian and minority ethnic population, and also, for some reason, among care home workers.

On a recent editorial board meeting of the European Journal of Hospital Pharmacy, it was clear that many hospital pharmacists are now involved in the vaccine rollout. It is imperative that as a profession, we can encourage all those eligible to get vaccinated as soon as possible. We need to keep abreast of the situation relying as far as possible on the evidence using all the assessment tools at our disposal and not being drawn in to speculative debates. While we may look with envy at the vaccination rates in some countries and with concern at vaccine rollout in others, the fact remains that none of us are the safe until all are safe, not just across Europe but globally as well.

\section{Competing interests None declared.}

Provenance and peer review Commissioned; internally peer reviewed.

(c) European Association of Hospital Pharmacists 2021. No commercial re-use. See rights and permissions. Published by BMJ.

(D) Check for updates

To cite Wiffen P. Eur J Hosp Pharm 2021;28:123. Published Online First 1 April 2021

Eur J Hosp Pharm 2021;28:123.

doi:10.1136/ejhpharm-2021-002809

ORCID iD

Philip Wiffen http://orcid.org/0000-0001-6085-1307

\section{REFERENCES}

1 Sackett DL, Rosenberg WM, Gray JA, et al. Evidence based medicine: what it is and what it isn't. BMJ 1996:312:71-2.

2 European Medicines Agency. EMA's safety committee continues investigation of COVID-19 Vaccine AstraZeneca and thromboembolic events - further update. Available: europa.eu [Accessed 23 Mar 2021]. 